\title{
PENGEMBANGAN LEMBAR KERJA SISWA FISIKA BERBASIS SCIENTIFIC PADA MATERI ELASTISITAS DAN HUKUM HOOKE
}

\author{
Mayang Sari, ${ }^{1}$ Ahmad Amin ${ }^{2}$, Wahyu Arini ${ }^{3}$ \\ mayangsari960328@gmail.com
}

${ }^{1,2,3}$ Program Studi Pendidikan Fisika STKIP PGRI Lubuklinggau, Sumatera Selatan, Indonesia

Received: 6 Maret 2021

Revised: 27 Mei 2021

Accepted: 16 Juni 2021

\begin{abstract}
This study aims to develop a scientific-based physics student worksheet on the subject of Elasticity and Hooke's Law which is valid and practical. The problems in this study are 1)How to design and develop scientific-based Physics Student Worksheets on Elasticity and Hooke's Law for Class XI SMA Negeri 4 (Model) Lubuklinggau?, 2)What is the quality of worksheets for learning physics when viewed from the point of view of validity practicality?, The subjects in this study were class XI IPA 5 which consisted of 6 students who were drawn by purposive sampling technique. Research development uses the ADDIE model which consists of 1)Needs Analysis, 2)Design, 3)Development, 4)Implementation, 5)Evaluation. The data was collected by using a student response questionnaire technique. And validation consists of 3 expert validations, material validation with an assessment of 44 in the very good category, language validation with a rating of 18 in the good category, and media validation with an assessment of 29 in the good category. Validation carried out to get results with an assessment of 91 in the good category. The student response to the Scientific-based physics Student Worksheets with a rating of 34.16 was in the very good category, while the results of the student competency test with 6 samples of 1 person did not complete 5 people who reached the KKM. So it can be said that the scientific-based physics student worksheet developed is valid and practical
\end{abstract}

Keywords: Student Worksheets, Scientific, Reseach and Development

Abstrak: Penelitian ini bertujuan untuk mengembangakan Lembar Kerja Siswa (LKS) Fisika Berbasis Scientific pada pokok bahasan Elastisitas dan Hukum Hooke yang valid, dan praktis. Masalah dalam penelitian ini adalah 1)Bagaimana mendesain dan mengembangkan Lembar Kerja Siswa Fisika berbasis scientific pada materi Elastisitas dan Hukum Hooke Kelas XI SMA Negeri 4 (Model) Lubuklinggau?, 2)Bagaimana kualitas LKS untuk pembelajaran fisika jika ditinjau dari segi kevalidan, dan kepraktisan?, Subjek dalam penelitian ini adalah kelas XI IPA 5 yang terdiri dari 6 siswa yang diambil dengan teknik purposive sampling. Pengembangan penelitian menggunakan model ADDIE yang terdiri dari 1)Analisis Kebutuhan (Analysis), 2)Perancangan (design), 3)Pengembangan (develop), 4)Implementasi (Implement), 5) Evaluasi (Evaluation). Pengumpulan data dilakukan dengan teknik angket respon siswa. Dan validasi terdiri dari 3 validasi ahli, validasi materi dengan penilaian 44 dalam kategori sangat baik, validasi bahasa dengan penilaian 18 dalam kategori baik, dan validasi media dengan penilaian 29 dalam kategori baik. Validasi yang dilakukan mendapatkan hasil dengan penilaian 91 dalam kategori baik. Respon siswa terhadap lembar kerja siswa fisika berbasis Scientific dengan penilaian 34,16 dalam kategori sangat baik sedangkan hasil uji kompetensi siswa dengan 6 orang sampel 1 orang tidak tuntas 5 orang yang mencapai KKM. Sehingga dapat dikatakan bahwa Lembar Kerja Siswa fisika berbasis Scientific yang dikembangkan telah Valid, dan praktis.

Kata kunci : LKS, Scientific, Reseach and Development

Puplished at https://ojs.stkippgri-lubuklinggau.ac.id/index.php/SJPIF 


\section{PENDAHULUAN}

Dalam pendidikan perkembangan kurikulum menuntut siswa untuk selalu aktif, kreatif dan inovatif dalam menanggapi setiap matapelajaran yang diajarkan. Kurikulum adalah seperangkat rencana dan pengaturan mengenai tujuan, isi, dan bahan pelajaran serta cara yang digunakan sebagai pedoman penyelenggaraan kegiatan pembelajaran untuk mencapai tujuan pendidikan tertentu. Kurikulum menjadi alat yang sangat penting bagi keberhasilan suatu pendidikan, baik formal maupun non formal (Agustin, I., Amin, A., \& Arini, W, 2019). Kurikulum adalah program pendidikan yang disediakan oleh sekolah untuk siswa, melalui program yang direncanakan tersebut siswa melakukan berbagai kegiatan belajar sehingga mendorong perkembangan dan pertumbuhannya sesuai dengan tujuan pendidikan (Restu, I. A., \& Arini, W, 2020). Berbagai upaya telah dilakukan oleh Kemendiknas untuk mewujudkan kualitas dan mutu pendidikan yang lebih baik. Salah satu upaya yang dilakukan oleh Kemendiknas adalah pengembangan kurikulum. Kemendiknas selalu melakukan pengembangan kurikulum sesuai dengan tuntutan zaman, dari kurikulum 1947 hingga kurikulum 2013 (K13) yang selalu direvisi sampai sekarang. Dalam kurikulum 2013 (K13), peserta didik dituntut untuk lebih aktif dalam proses pembelajaran dan guru hanya berperan sebagai fasilitator dan motivator (Lorenza, Y., Sasmita, P. R., \& Amalia, S, 2019).

Proses pembelajaran itu sendiri berupa hubungan interaksi antara siswa, guru, perlengkapan dan kurikulum. Suatu kegiatan pembelajaran dapat dikatakan berjalan dengan baik dan efektif apabila hubungan interaksi tersebut dapat saling mendukung. Guru sebagai salah satu komponen hubungan interaksi pada proses pembelajaran, bertugas membimbing dan mengarahkan siswa belajar dan bagaimana supaya mendapatkan hasil belajar yang maksimal. Besar kecilnya peranan guru dalam proses pembelajaran untuk mencapai hasil belajar yang baik sangat tergantung pada tingkat penguasaan materi, pemilihan pendekatan, metode yang digunakan dan model pembelajaran yang akan dipakai (Ariani, T, 2017). Guru menjadi pemimpin belajar yang memberi fasilitas belajar dan lingkungan yang kondusif yang memungkinkan siswa untuk belajar dengan nyaman (Gumay, O. P. U., Kodarsih, E., \& Mulyanto, A. B, 2016).

Salah satu mata pelajaran yang diajarkan dalam pendidikan formal di sekolah adalah Fisika. Fisika merupakan ilmu yang mempelajari tentang fenomena gejala alam dan tak lepas dari penerapan kehidupan sehari-hari. Fisika juga merupakan ilmu universal yang mendasari perkembangan teknologi modern dan mempunyai peran penting dalam berbagai disiplin ilmu 
dan mengembangkan daya pikir manusia. Untuk menguasai dan meciptakan teknologi dimasa depan diperlukan penguasaan konsep-konsep Fisika sejak dini dan dilakukan suatu tindakan yang terencana. Oleh karena itu, Fisika berperan mempersiapkan siswa atau generasi penerus agar dapat menghadapi tantangan-tantangan di kehidupan yang semakin berkembang dan modern (Ariani, T., \& Yolanda, Y, 2019).

Berdasarkan observasi yang telah dilakukan pada tanggal 14-19 november 2019 menggunakan teknik wawancara dengan guru Fisika dan siswa kelas XI IPA SMA Negeri 4 Lubuklinggau didapatkan hasil bahwa SMA Negeri 4 Lubuklinggau menggunakan kurikulum 2013 revisi 2018. Dengan menggunakan kurikulum terbaru sebagian besar siswa masih mengalami kesulitan dalam menjalankan kurikulum 2013. Dalam kurikulum 2013 menggunakan pendekatan scientific dalam proses KBM. Sebagian besar siswa di kelas kesulitan saat menerapkan pendekatan scientific kedalam proses KBM diantaranya materi yang belum dipahami oleh siswa ialah elastisitas dan hukum hooke, inilah yang menyebabkan rendahnya pemahaman siswa terhadap konsep dan praktikum yang ada dalam materi, hal tersebut membuat siswa mengikuti proses belajar belum optimal. Siswa juga menuturkan bahwa mereka lebih suka belajar dengan menggunakan metode praktikum dibandingkan belajar di dalam kelas. Banyak faktor yang mempengaruhi hal tersebut misalnya cara penyampaian materi oleh guru yang monoton, tidak menarik, pembelajaran hanya mengandalkan buku paket atau dari penerbit sebagai sumber belajar, kurangya lembar kerja siswa, serta kurangnya peralatan praktikum. Siswa mengharapkan sebuah buku ajar yang memiliki tampilan menarik dan tidak membosankan serta dapat memotivasi siswa dalam belajar Fisika.

Dari wawancara didapatkan pula bahwa Lembar kerja siswa yang digunakan masih kurang. Lembar kerja siswa yang ada di buku paket atau buku dari penerbit. Di dalam buku paket tersebut kurang mendukung dengan model pembelajaran yang digunakan untuk kurikulum 2013 sekarang. Dalam buku paket tersebut lembar kerja siswa yang disediakan belum lengkap karena lembar kerja siswa yang digunakan hanya melihat dari buku cetak tanpa adanya lembar kerja siswa yang detail. Sedangkan dalam kurikulum 2013 siswa dituntut agar lebih aktif dengan menggunakan pendekatan scientific. Berdasarkan latar belakang permasalahan yang telah dikemukakan di atas, penulis tertarik untuk melakukan penelitian dengan judul "Pengembangan Lembar Kerja Siswa Fisika Berbasis Scientific Pada Materi Elastisitas dan Hukum Hooke Siswa Kelas XI SMA Negeri 4 Lubuklinggau Tahun Ajaran 2020/2021". Tujuan dari dilakukannya penelitian ini adalah: 1)Untuk mengetahui 
cara mendesain dan mengembangkan lembar kerja siswa Fisika berbasis scientific pada materi elastisitas dan hukum hooke Kelas XI SMA Negeri 4 Lubuklinggau, 2)Untuk mengetahui kualitas Lembar kerja siswa Fisika berbasis scientific pada materi Elastisitas dan Hukum Hooke Siswa Kelas XI SMA Negeri 4 Lubuklinggau.

\section{LANDASAN TEORI}

Gagne dan Brings (2003) pengembangan adalah suatu sistem pembelajaran yang bertujuan untuk membantu proses belajar peserta didik, yang berisi serangkaian peristiwa yang dirancang untuk mempengaruhi dan mendukung terjadinya proses belajar yang bersifat internal atau segala upaya untuk menciptakan kondisi dengan sengaja agar tujuan pembelajaran dapat tercapai. Borg and Gall (dalam Sugiyono, 2015) adalah proses atau metode yang digunakan untuk memvalidasi dan mengembangkan produk. Pengertian lain yang di jelaskan oleh Sugiyono (2015) penelitian dan pengembangan berfungsi untuk memvalidasi dan mengembangkan produk. Memvalidasi produk berarti produk itu telah ada, dan peneliti hanya menguji validitas produk tersebut.

Dalam penelitian pengembangan terdapat banyak model pengembangan yang dikemukakan oleh ahli untuk dipakai pada saat melakukan penelitian pengembangan. Setiap model pengembangan yang dikemukakan memiliki tahapan-tahapannya sendiri. Model penelitian pengembangan yang dikemukakan para ahli antara lain model kemp, model ADDIE, model 4-D, model dick and carey, serta model Borgh and Gall.

Dalam penelitian ini akan menggunakan model penelitian pengembangan milik ADDIE. Model pengembangan ADDIE ini dipilih karena dalam langkah penelitianya yang uraiannya lebih lengkap, terperinci dan sistematis. Model pengembangan ADDIE adalah model pengembangan yang memiliki langkah-langkah sistematis dan interaktif.

Pengembangan model ADDIE merupakan model pengembangan perangkat pembelajaran model pengembang ini ADDIE terdiri atas 5 tahap utama yaitu: Analisis (Analysis), Desain (Design), Pengembangan (Develop), Implementasi (Implement), dan Evaluasi (Evaluate). Model ADDIE bergantung pada setiap tahap yang dilakukan dalam urutan yang diberikan, namun dengan fokus pada refleksi dan literasi. Model ini memberi pendekatan yang terfokus pada pemberian umpan balik untuk perbaikan terus-menerus. Model desain instruksional ADDIE (Analysis-Desain-Develop-Implement-Evaluate) yang dikembangkan oleh Reiser dan Molenda (2010) merupakan model desain pembelajaran/pelatihan yang bersifat generik 
menjadi pedoman dalam membangun perangkat dan infrastruktur program pelatihan yang praktis, dinamis dan mendukung kinerja pelatihan itu sendiri.

Adapun bagan langkah-langkah penelitian berdasarkan model pengembangan ADDIE seperti ditunjukkan pada gambar berikut:

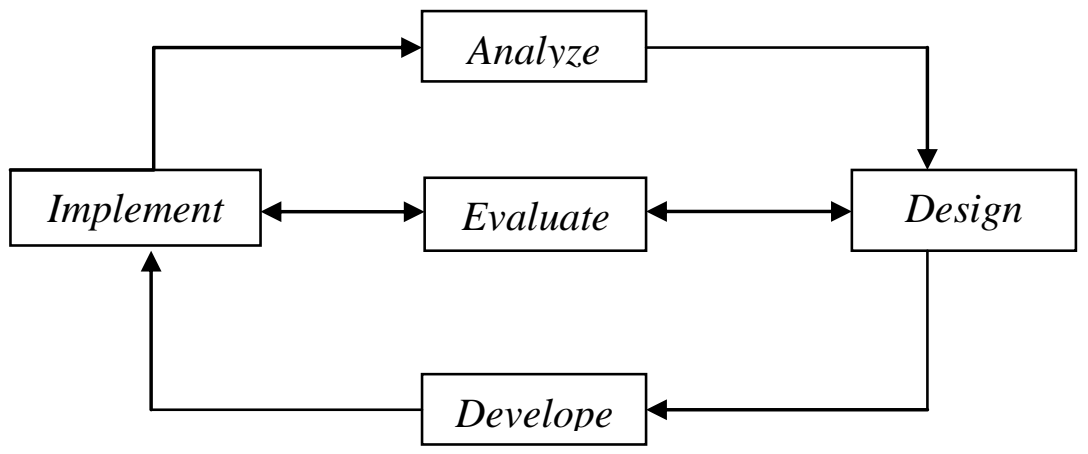

Gambar 1. Langkah-langkah Model Pengembangan ADDIE (Peterson, 2003)

\section{a. Lembar Kerja Siswa}

LKS merupakan lembaran-lembaran berisi petunjuk, tuntunan pertanyaan yang harus dikerjakan oleh siswa agar dapat memperluas serta memperdalam pemahamannya terhadap materi yang dipelajari (Depdiknas, 2008). LKS biasanya berupa petunjuk, langkah untuk menyelesaikan suatu tugas, suatu tugas yang diperintahkan dalam lembar kegiatan harus jelas kompetensi dasar yang akan dicapainya. (Depdiknas, 2004) mendefinisikan bahwa LKS adalah panduan siswa yang digunakan untuk melakukan kegiatan penyelidikan dan pemecahan masalah. LKS merupakan lembaran-lembaran berisi petunjuk, tuntunan pertanyaan yang harus dikerjakan oleh siswa agar dapat memperluas serta memperdalam pemahamannya terhadap materi yang dipelajari (Depdiknas, 2008). Selain sebagai media pembelajaran, Prastowo (2014) beberapa fungsi lain dari LKS, yaitu: meminimalkan peran guru, sehingga dapat mengoptimalkan keaktifan siswa. Sebagai bahan yang memudahkan siswa dalam memahami materi. Sebagai bahan yang ringkas dan kaya tugas untuk berlatih. Memudahkan pelaksanaan pembelajaran kepada siswa.

Penulisan LKS dapat dilakukan dengan langkah-langkah sebagai berikut: perumusan kompetensi dasar yang harus dikuasai. Rumusan kompetensi dasar (KD) pada LKS disesuaikan dengan kurikulum. Menentukan alat penilaian dilakukan terhadap proses kerja dan hasil kerja siswa. Pendekatan pembelajaran yang digunakan adalah penguasaan kompetensi. Penyusunan materi Materi LKS sangat bergantung pada kompetensi dasar (KD) yang akan dicapai. Materi dapat diambil dari berbagai sumber, misal: buku, majalah, internet, jurnal penelitian. Struktur LKS, Struktur LKS terdiri atas: judul, petunjuk belajar (petunjuk Puplished at https://ojs.stkippgri-lubuklinggau.ac.id/index.php/SJPIF 
siswa), kompetensi yang akan dicapai, informasi pendukung, tugas-tugas dan langkahlangkah kerja, serta penilaian.

Dalam penelitian ini lembar kerja siswa yang dikembangkan berbasis scientific. artinya lembar kerja siswa yang dikembangkan menggunakan tahap-tahap dari scientific untuk struktur dalam lembar kerja siswa. Lembar kerja siswa memiliki kelebihan yaitu praktis dibawa kemana-mana, ringan, dan cepat mudah diakses.

\section{b. Pendekatan Sclentıfic}

Pendekatan pembelajaran scientific adalah pembelajaran yang merujuk pada teknikteknik investigasi atas fenomena atau gejala memperoleh pengetahuan baru atau mengoreksi, dan memadukan pengetahuan sebelumnya. Pendekatan pembelajaran dapat disebut ilmiah (saintifik), metode pencarian (method of inquiry) harus berbasis pada bukti-bukti dari objek yang dapat diobservasi, empiris, dan terukur dengan prinsip-prinsip penalaran yang spesifik. Karena itu, metode ilmiah (saintifik) umumnya memuat serial aktivitas pengoleksian data melalui observasi dan ekperimen, kemudian memformulasi dan menguji hipotesis (Susilo, dkk, 2016) Dalam definisi lain Pendekatan saintifik (scientific approach) merupakan salah satu pendekatan pembelajaran yang berorientasi atau berpusat pada siswa (Yerimadesi, 2016).

Berdasarkan pendapat beberapa ahli di atas dapat disimpulkan bahwa pendekatan scientific adalah pendekatan yang merujuk pada teknik-teknik investigasi atas fenomena atau gejala untuk mendapatkan pengetahuan baru dan pembelajaran yang berorientasi pada siswa. Pendekatan scientific memiliki 5 tahapan di dalamnya. Tahapan tersebut yaitu: Mengamati, menanya, mengumpulkan informasi/data, menalar, mengkomunikasikan.

\section{METODE PENELITIAN}

Pengembangan LKS ini menggunakan jenis penelitian pengembangan (research and development). Metode penelitian dan pengembangan adalah metode penelitian yang digunakan untuk menghasilkan produk tertentu dan menguji keefektifan produk tersebut. Dalam penelitian ini untuk mengembangkan sebuah bahan ajar berbasis scientific pada materi elastisitas dan hukum hooke menggunakan model pengembangan ADDIE. Dimana dalam penelitian ini memiliki 5 langkah. Adapun langkah dari pengembangan model ADDIE terdapat 5 tahapan yaitu: analisis, desain, pengembangan, implementasi dan evaluasi. Teknik pengumpulan data dalam penelitian ini menggunakan angket, wawancara dan uji kompetensi. Adapun instrumen yang digunakan untuk melihat valid dan praktis lembar kerja siswa yang 
dikembangkan yaitu menggunakan, angket kevalidan, angket kepraktisan, wawancara dan uji kompetensi.

Lembar kerja siswa dikembangkan menggunakan ms word, photoshop, dan photoscape. Lembar kerja siswa draf final ini adalah lembar kerja siswa yang akan digunakan dalam penelitian di SMA Negeri 4 Lubuklinggau Dimana hasil dari desain yang dilakukan oleh peneliti harus melalui tahap divalidasi oleh para validator yang ahli di bidangnya masingmasing. Validator yang akan memvalidasi lembar kerja siswa yang dikembangkan adalah ahli materi oleh ibu Ovilia Putri Utami Gumay, M.Pd.Si ahli tata bahasa dilakukan oleh ibu Dr. Rusmana Dewi, M.Pd serta ahli media dilakukan oleh bapak Dr. Dodik Mulyono, M.Pd.

Peneliti menggunakan desain One Shot Case Study dimana peneliti hanya melihat hasil akhir dari sebuah penelitian. Peneliti melakukan 1 tahap pengujian yaitu dengan menggunakan Perorongan. Pada uji perorangan peneliti memberikan angket dengan 6 orang siswa kelas XI MIPA 5. Angket ini berisi 10 pernyataan yang harus diberikan tanggapan oleh siswa. Pada akhirnya tahap uji perorangan dilakukan di kelas XI MIPA 5 SMAN 4 Lubuklinggau dengan menggunakan 10 soal uji kompotensi sebagai instrumen pengujian keefektifan produk.

Untuk menghitung skor angket menggunakan rumus:

$$
\overline{\mathrm{x}}=\frac{\Sigma x}{n}
$$

keterangan: $\overline{\mathrm{x}}$ : skor rata-rata

(Sumber Sudjana, 2017)

$\Sigma \mathrm{x}$ : jumlah skor

$\mathrm{n} \quad$ : jumlah penilai

\section{HASIL DAN PEMBAHASAN}

Pada penelitian ini dipilih 1 pokok bahasan materi, materi yang dipilih untuk pengembangan lembar kerja siswa berbasis pendekatan scientific ini adalah materi elastisitas dan hukum hooke. Pembelajaran akan dilaksanakan dua kali dalam 1 minggu. Dalam satu pertemuan dengan waktu 2 x 45 menit dalam satu hari maka sebisa mungkin guru memanfaatkan waktu yang diberikan agar bisa mencapai keterlaksanaan pembelajaran yang maksimal. Peneliti mengambil 1 materi saja karena mengingat adanya keterbatasan waktu dan biaya penelitian. Serta dimaksudkan untuk membantu mempermudah siswa dalam memahami materi yang diajarkan.

Lembar kerja siswa yang akan dikembangkan akan didesain dengan menggunakan program photoshop, photoschape, dan ms word. Lembar kerja siswa yang dikembangkan Puplished at https://ojs.stkippgri-lubuklinggau.ac.id/index.php/SJPIF 
didesain semenarik mungkin dengan tampilan yang menarik dan perpaduan warna yang dapat menarik perhatian siswa untuk belajar. Selain itu dalam Lembar kerja siswa nantinya akan mengunakan beberapa tambahan gambar kartun dan gambar yang sesuai dengan materi yang digunakan. Gambar digunakan untuk membuat siswa lebih paham dengan materi dan membuat siswa tidak jenuh dan bosan dalam membaca buku.

Lembar kerja siswa ini dibuat dengan 2 macam yaitu lembar kerja siswa bagi guru dan lembar kerja siswa bagi siswa. Lembar kerja siswa didalamnya memuat materi,, contoh soal dan pembahasannya, soal latihan dan pembahannya, serta soal evaluasi dan penyelesaiannya. Sedangkan pada buku siswa terdapat materi, Lembar Kerja Praktikum, contoh soal, dan soal latihan. Lembar kerja siswa yang dikembangkan melewati beberapa tahapan untuk mendapatkan lembar kerja siswa final atau lembar kerja siswa yang digunakan untuk penelitian.

Pada lembar kerja siswa draf 1 , peneliti telah merancang lembar kerja siswa berbasis scientific dengan materi elastisitas dan hukum hooke yang belum divalidasi dan belum dinilai. Lembar kerja siswa yang dikembangkan adalah yang paling awal dan sangat sederhana. Lembar kerja siswa dikembangkan menggunakan ms word, photoshop, dan photoscape. Lembar kerja siswa yang dikembangkan terdiri dari dua buku yaitu: LKS siswa dan LKS guru.

Setelah LKS draf 1 selesai dirancang, selanjutnya peneliti melakukan validasi kepada validator ahli. Jika sudah di validasi oleh validator, lalu mendapatkan saran dan masukan oleh validator untuk mendapatkan nilai valid atau kevalidan oleh validator maka di susun kembali LKS draf 2 dan di koreksi kembali oleh validator, setelah LKS draf 2 selesai, maka akan di peroleh LKS final.

Dari LKS draf 1 dan draf 2 yang telah di nilai dan di koreksi oleh validator ahli, dosen Fisika, dan guru Fisika akhirnya didapat LKS final yang dapat digunakan dalam penelitian. Lembar kerja siswa dikembangkan menggunakan ms word, photoshop, dan photoscape. Lembar kerja siswa draf final ini adalah lembar kerja siswa yang akan digunakan dalam penelitian di SMA Negeri 4 Lubuklinggau. Berikut lembar kerja siswa final dapat dilihat pada gambar 2 . 


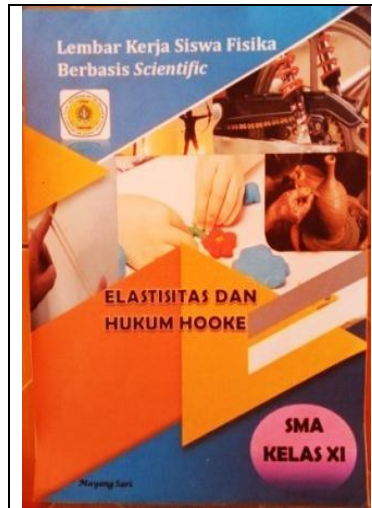

Cover LKS draf final

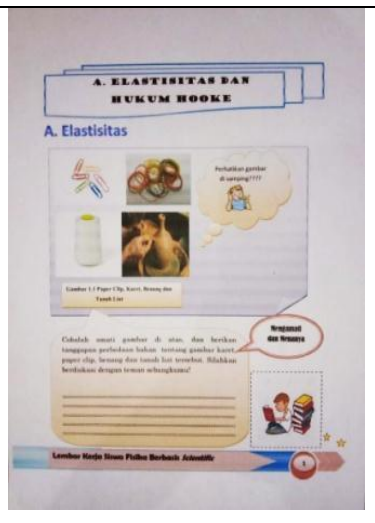

Isi LKS draf final

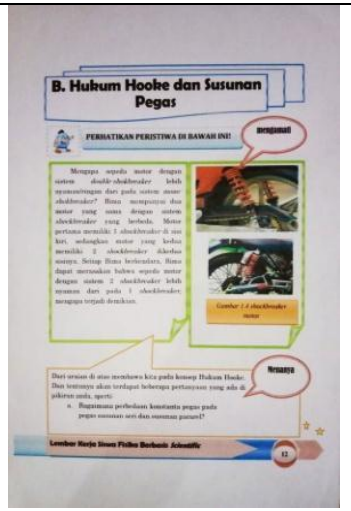

Isi LKS draf final

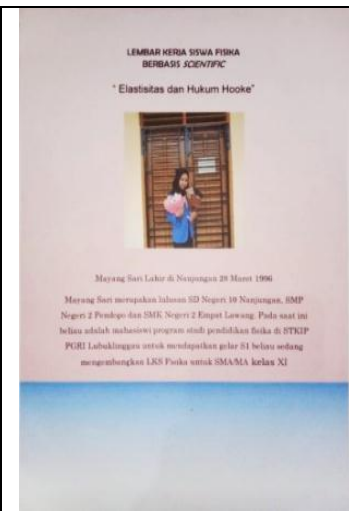

Cover LKS draf final

\section{Gambar 2. Draf LKS Final}

Setelah melewati beberapa kali revisi, pada LKS final ini penulis tetap memberikan LKS kepada para ahli untuk dinilai. Pada LKS final, ahli materi memberikan nilai sangat baik dan ahli media memberikan nilai baik dan tanpa ada yang harus diperbaiki. Sedangkan untuk ahli bahasa juga memberikan nilai yang baik, tetapi hanya ada satu kata pengetikan yang kurang tepat. Untuk ahli bahasa menyarankan tidak perlu melakukan perbaikan yang banyak hanya merevisi pengetikan kata yang salah.

\section{a. Kelayakan Lembar Kerja Siswa}

Kelayakan dari lembar kerja siswa Fisika berbasis scientific ini dilihat dari hasil validasi yang dilakukan kepada beberapa ahli dan dari beberapa aspek. Evaluasi ahli dilakukan untuk menyempurnakan lembar kerja siswa yang dikembangkan dari segi materi, media, dan bahasa. Sebagai ahli materi dipilih seorang dosen prodi Fisika yaitu Ibu Ovilia Putri Utami Gumay, M.Pd.Si Sebagai ahli media dipilih dosen prodi Fisika yaitu bapak Dr. Dodik Mulyono, M.Pd. Sedangkan sebagai ahli bahasa dipilih seorang dosen prodi bahasa Indonesia yaitu ibu Dr.Rusmana Dewi, M.Pd. Ketiga validator ini dipilih melalui rekomendasi dari pihak LP4MK STKIP-PGRI Lubuklinggau untuk memberikan penilaian dan saran terhadap lembar kerja siswa yang peneliti kembangkan. Instrumen yang digunakan adalah angket terbuka, berdasarkan indikator dan saran yang dibutuhkan dalam mengembangkan lembar kerja siswa berbasis scientific. Secara rinci peneliti uraikan sebagai berikut.

Validasi materi dilakukan kepada validator ahli materi yaitu kepada dosen Fisika STKIP PGRI Lubuklinggau. Validasi materi yang dilakukan kepada dosen Fisika yaitu Ibu Ovilia Putri Utami Gumay, M.Pd.Si sebanyak tiga kali. Hal ini dimaksudkan untuk memaksimalkan dan agar materi dalam lembar kerja siswa yang dikembangkan semakin baik. Dari hasil analisis validasi yang ketiga ini termasuk dalam kategori sangat baik yaitu 44 termasuk 
kedalam kategori sangat baik. Artinya lembar kerja siswa fisika yang dikembangkan memiliki progres peningkatan yang baik dari setiap validasinnya.

Validasi Kedua adalah hasil dari validasi tata bahasa. Validasi tata bahasa dilakukan kepada ahli bahasa yaitu dosen bahasa indonesia, ibu Dr. Rusmana Dewi, M.Pd. Validasi yang dilakukan dari segi tata bahasa ini hanya dilaksanakan satu kali. Hasil tanggapan dari validasi komponen tata bahasa mendapatkan skor 18. Dari hasil yang didapat termasuk dalam kategori baik lembar kerja siswa yang dikembangkan layak digunakan dari tata bahasa dengan tetap adanya beberapa revisi sesuai dengan saran. Ibu Dr. Rusmana Dewi, M.Pd.

Validasi ketiga adalah hasil dari validasi media atau desain. Validasi media atau desain dilakukan kepada ahli media desain yang ada di STKIP PGRI Lubuklinggau yaitu salah satu dosen matematika yang menjadi ahli media di STKIP PGRI Lubuklinggau yaitu bapak Dodik Mulyono, M.Pd. Hasil tanggapan dari validasi komponen tata bahasa mendapatkan skor 29. Dari hasil analisis validasi ini termasuk dalam kategori baik lembar kerja siswa yang dikembangkan layak digunakan dari segi media desain dengan tetap adanya beberapa revisi sesuai dengan saran.

Berdasarkan hasil penilaian tahap validasi oleh para ahli yang telah dilakukan terhadap lembar kerja siswa berbasis scientific yang telah diuraikan di atas menunjukkan maka kevalidan lembar kerja siswa termasuk dalam kategori baik sehingga lembar kerja siswa yang dikembangkan layak untuk digunakan dalam kegiatan belajar mengajar dengan tetap melakukan perbaikan sesuai dengan saran dan komentar yang diberikan dan lembar kerja siswa berbasis scientific dapat digunakan untuk tahap selanjutnya yaitu uji coba yang akan dilaksanakan di SMA Negeri 4 Lubuklinggau. Hasil validasi yang telah dilaksanakan oleh ketiga ahli dapat dilihat pada tabel 1 .

Tabel 1. Rekapitulasi Tanggapan Ketiga Ahli

\begin{tabular}{cccc}
\hline No. & Validator & $\begin{array}{c}\text { Hasil } \\
\text { Penilaian }\end{array}$ & Kategori \\
\hline 1 & Validasi Materi & 44 & Sangat Baik \\
\hline 2 & Validasi Media & 29 & Baik \\
\hline 3 & Validasi Tata Bahasa & 18 & Baik \\
\hline & Total & 91 & Baik \\
\hline
\end{tabular}

\section{b. Kepraktısan Lembar Kerja Siswa}

Kepraktisan lembar kerja siswa di ujikan dengan melewati beberapa uji coba. Uji coba yang dilakukan adalah uji coba melalui tahapan uji coba perorangan untuk melihat kepraktisan lembar kerja siswa yang dilaksanakan di SMA Negeri 4 Lubuklinggau. Uji coba 
perorangan dilaksanakan pada rabu, 22 Juli 2020, dengan melakukan wawancara kepada enam orang siswa kelas XI MIA 5. Uji coba perorangan dilakukan di dalam kelas pada saat jam pelajaran Fisika. Hal ini dikarenakan guru Fisikanya yaitu ibu Feny Nisvalisia, M.Pd.Si telah memberikan izin untuk menggunakan kelasnya. Langkah-langkah yang dilakukan dalam uji coba perorangan adalah: (a) siswa diminta untuk membaca atau melihat-lihat sekilas lembar kerja siswa berbasis scientific selama \pm 5 menit; (b) siswa diminta untuk memperhatikan materi yang diambil secara acak sebagai sampel untuk ditanyakan; (c) setelah itu siswa mengisi angket respon siswa.

Pelaksanaan uji coba perorangan yang dilakukan oleh enam siswa menyatakan bahwa lembar kerja siswa berbasis scientific sangat menarik dilihat dari segi penampilan, desain, dan matei yang digunakan. Materi yang disajikan mudah dipahami karena penyajiannya lengkap beserta gambar dan kesesuaian antara gambar dengan ilustrasi sangat tepat dan dapat membuat materi lebih mudah dimengerti. Pada tahap uji coba perorangan lembar kerja siswa berbasis scientific didapatkan hasil dari pelaksanaan tahap uji coba perorangan bahwa tidak ada masukan maupun perbaikan dari yang disarankan, itu artinya lembar kerja siswa tersebut dapat sudah dapat digunakan di SMAN 4 Lubuklinggau.

Angket yang diberikan untuk penilaian lembar kerja siswa berbasis scientific ndikatornya sama seperti lembar wawancara yaitu, 1) kemenarikan bahan pembelajaran Fisika, 2) keterbacaan materi, dan 3) kemudahan pemahaman materi. Dari angket respon siswa yang telah diberikan mendapatkan nilai 34,14 termasuk dalam kategori sangat baik yang dikembangkan sudah baik dan sesuai dengan yang mereka inginkan.

Dari uji coba yang dilakukan terhadap siswa dengan menggunakan angket didapatkan hasil data kepraktisan lembar kerja siswa Fisika berbasis berbasis scientific materi Elastisitas dan Hukum Hooke di kelas XI SMA Negeri 4 Lubuklinggau yaitu cukup praktis sehingga dapat digunakan di SMAN 4 Lubuklinggau.

Tabel 2. Hasil Rekapitulasi Penilaian Angket Kepraktisan Uji Perorangan

\begin{tabular}{ccc}
\hline Kode Siswa & Skor & Keterangan \\
\hline S-1 & 32 & Baik \\
\hline S-2 & 35 & Sangat Baik \\
\hline S-3 & 37 & Sangat Baik \\
\hline S-4 & 34 & Sangat Baik \\
\hline S-5 & 34 & Sangat Baik \\
\hline S-6 & 35 & Sangat Baik \\
\hline Jumlah & \multicolumn{2}{c}{205} \\
\hline Rata-rata & & 34,16
\end{tabular}


Uji coba kepraktisan dilakukan karena sesuai dengan model pengembangan yang digunakan mengenai lembar kerja siswa Fisika berbasis scientific materi Elastisitas dan Hukum Hooke. Angket yang diberikan siswa dianjurkan untuk mengisi saran atau komentar di tempat yang telah disediakan. Dalam hal ini tidak ada saran dan komentari dari siswa kelas XI MIA 5 SMAN 4 (Model) Lubuklinggau.

Komentar yang diberikan menunjukkan bahwa lembar kerja siswa yang dikembangkan telah sangat baik dan praktis untuk digunakan dalam pembelajaran. Melihat lembar kerja siswa berbasis scientific yang dikembangkan bisa digunakan di SMA N 4 (Model) Lubuklinggau tanpa harus direvisi kembali. Dengan adanya komentar, peneliti mengetahui hal-hal yang dipikirkan siswa mengenai lembar kerja siswa yang diproduksi sehingga lembar kerja siswa bisa dikatakan praktis. Terbukti dengan banyaknya siswa yang merespon setuju untuk pernyataan yang dituliskan pada angket yang diberikan.

\section{KESIMPULAN}

Berdasarkan hasil penelitian dengan menggunakan lembar kerja siswa fisika berbasisis Scientific pada materi elastistas dan hukum hooke di SMA Negeri 4 (Model) Lubuklinggau tahun pelajaran 2020/2021 pada semester ganjil sebagai berikut :

Lembar kerja siswa fisika berbasis Scientific menggunakan model penelitian dan pengembangan ADDIE melalui 5 tahapan model pengembangan ADDIE yaitu (1) Analisis (Analysis, (2) Desain (Design), (3) Pengembangan (Develop), (4) Implementasi (Implement), (5) Evaluasi (Evaluate).

Lembar kerja siswa fisika berbasis Scientific pada materi elastisitas dan hukum hooke yang telah dikembangkan dievaluasi oleh ahli dan direvisi sesuai dengan kritik, saran dan tanggapan dari para ahli sehingga lembar kerja siswa fisika Scientific dikatakan valid dan memenuhi kriteria sangat baik dan hasil angket respon siswa uji kelompok kecil mendapatkan hasil dalam kategori sangat baik sehingga lembar kerja siswa fisika berbasis scientific sudah praktis untuk digunakan, sehingga dapat disimpulkan bahwa lembar kerja siswa fisika berbasis scientific sudah dapat digunakan karena sudah memenuhi kevalidan dan kepraktisan.

\section{DAFTAR PUSTAKA}

Agustin, I., Amin, A., \& Arini, W. (2019). Penerapan Pendekatan Scientific terhadap Aktivitas Belajar Fisika Siswakelas X SMA Negeri 3 Lubuklinggau Tahun Pelajaran 2018/2019. Silampari Jurnal Pendidikan Ilmu Fisika, 1(2), 121-129. 
Ariani, T. (2017). Pembelajaran Kooperatif Tipe Team Assisted Individualization (TAI): Dampak Terhadap Hasil Belajar Fisika Siswa. Jurnal Ilmiah Pendidikan Fisika AlBiRuNi, 6(2), 169-177.

Ariani, T., \& Yolanda, Y. (2019). Effectiveness of Physics Teaching Material Based on Contextual Static Fluid Material. Kasuari: Physics Education Journal (KPEJ), 2(2), $70-81$.

Arini, W. (2020). Implementation of Scientific Approach in Physics. THABIEA: Journal Of Natural Science Teaching, 3(2), 152-162.

Aunurrahman. (2016). Belajar dan Pembelajaran. Bandung : Alfabeta.

Bloom, B.S., Engelhart, M.D., Furst, E.J., Hill, W.H., dan Krathwohl, D.R. (2010). The Taxonomy of Educational Objectives The Classification of Educational Goals, Handbook I: Cognitive Domain. New York: David Mc Kay.

Damayanti, dkk. (2013). Pengembangan lembar kerja siswa (lks) dengan pendekatan inkuiri terbimbing untukn mengoptimalkan kemampuan berpikir kritis peserta didik pada materi peserta didik pada materi listik dinamis. Jornal program studi pendidikan fisika. universitas muhammadiyah purworejo. Vol. 3. No. 1. Hal 58-62.

Depdiknas. (2008). Kurikulum Tingkat Satuan Pendidikan. Jakarta: Dikmenum. Depdiknas.

Fatmawati. (2016). Metodologi Penelitian Kuantitatif dan Kualitatif. Yogyakarta: Yayasan Kareadarma.

Gagne, B,. (2003). Kondisi Belajar dan Pembelajaran. Jakarta: Departemen Pendidikan dan Kebudayaan.

Gumay, O. P. U., Kodarsih, E., \& Mulyanto, A. B. (2016). Pengaruh Model Pembelajaran Kooperatif Tipe Student Teams Achievement Division (STAD) Terhadap Hasil Belajar Fisika Siswa Kelas X SMA Negeri 2 Muara Beliti Tahun Pelajaran 2015/2016. In Prosiding Seminar Nasional Fisika (E-Journal) (Vol. 5, pp. SNF2016-EER).

Lestari, W. M., Ariani, T., \& Gumay, O. P. U. (2018). Pengembangan Bahan Ajar Fisika Berbasis Scientific Approach. SPEJ (Science and Physic Education Journal), 2(1), 18-29.

Lorenza, Y., Sasmita, P. R., \& Amalia, S. (2019). Pengaruh Model Pembelajaran Inkuiri Terbimbing Berbantukan Alat Peraga Sederhana Terhadap Hasil Belajar Fisika Peserta Didik. Silampari Jurnal Pendidikan Ilmu Fisika, 1(2), 87-93.

Pudjawan, K., Jampel, I, N., \& Tegeh, I, M. (2014). Model Penelitian Pengembangan. Yogyakarta: Graha Ilmu.

Reksoatmodjo, N., T. (2010). Pengembangan Kurikulum Pendidikan Teknologi dan Kejuruan. Bandung: Refika Aditama.

Restu, I. A., \& Arini, W. (2020). Pengembangan LKS Fisika Berbasis Contextual Teaching and Learning Materi Suhu dan Kalor Pada Siswa Kelas XI SMA Negeri 6 Lubuklinggau. SILAMPARI JURNAL PENDIDIKAN ILMU FISIKA, 2(2), 92-106.

Riduwan. (2014). Skala Pengukuran Variabel-variabel Penelitian. Bandung: Alfabeta. 
Shelton, dkk. (2008). Applying the ADDIE Model to Online Instruction. Jounal 64 Tekno, Vol: 22 September 2014, ISSN : 1693-8739.

Sudijono. (2013). Pengantar Evaluasi Pendidikan. Jakarta: Rajawali Pers.

Sugiyono. (2017). Metode Penelitian Kuantitatif, Kualitatif, dan R\&D. Bandung: Alfabeta. CV.

Sukiman. (2012). Pengembangan Media Pembelajaran. Yogyakarta: Pedagogia.

Trianto. (2009). Mendesain Model Pembelajaran Inovatif-Progresif. Jakarta: Kencana

Widya, dkk,. (2017). Kualitas Perangkat Pembelajaran Fisika Berbasis Model Crewative Problem Solving Dengan Pendekatan Open-Ended Pada Materi Usaha Dan Energi Terintegrasi Energi Biomassa. Gravity: Jurnal Ilmiah Peneliti dan Pembelajaran Fisika. 3(2), 162, 164 dan 166

Yerimadesi. (2016). Pengembangan modul kesetimbangan kimia berbasis pendekatan saintifik. Jounal of sainstek 8 